\title{
Tumor-primed NK cells: waiting for the green light
}

\author{
May Sabry and Mark W. Lowdell* \\ Department of Haematology, Royal Free Campus, University College London Medical School, London, UK
}

\section{Edited by:}

Aurore Saudemont, Anthony

Nolan/University College London, UK

Reviewed by:

Chiara Romagnani, Deutsches

Rheuma Forschungszentrum,

Germany

Ennio Carbone, University of

Catanzaro Magna Graecia, Italy

${ }^{*}$ Correspondence:

Mark W. Lowdell, Department of Haematology, Royal Free Campus,

University College London Medical

School, Rowland Hill Street, London

NW3 2PF, UK

e-mail:m.lowdell@ucl.ac.uk

\begin{abstract}
The functional impairment of natural killer (NK) cells has been frequently reported in cancer studies. As one of the central components of host anti-tumor immunity, NK cells exert cellular cytotoxicity against tumor cells, and secrete a cytokine milieu to inhibit tumor progression and enable the recruitment of other immune cells to the tumor site. The unlocking of the full functional potential of NK cells requires successful progression through discrete activation stages that are tightly regulated by a complex array of signaling molecules. Target cell susceptibility to NK cell-mediated killing is dependent on the intensity and specific combination of ligand expression for NK cell receptors. Tumor cells utilize numerous strategies for evading NK cells, including the downregulation of important NK cell-activating ligands. Here, we review key studies on NK cell activation requirements, and argue, based on our findings from NK cell-tumor interactions, that the altered characteristics of tumorassociated NK cells are indicative of unmet signaling requirements for full NK cell activation, rather than NK cell dysfunction in cancer.
\end{abstract}

Keywords: natural killer cells, NK cell dysfunction, cancer immunotherapy, CTV-1, LFA-1, NKG2D

\section{INTRODUCTION}

Natural killer (NK) cells were first identified in 1975, based on their ability to spontaneously lyse tumor cells in the absence of $\mathrm{T}$ and B lymphocytes (1-4). After over 30 years, our understanding of NK cell biology and function lends important insights into their critical role in infection, autoimmunity, hematopoietic stem cell (HSC) transplantation, reproduction as well as tumor immunosurveillance. Besides exhibiting cytotoxicity against a variety of "stressed" cells, NK cells also secrete a milieu of cytokines that participate in shaping adaptive immune responses (5). NK cells share many similarities with cytotoxic $\mathrm{T}$ cells (CTLs), including a common progenitor cell, a wide array of cell surface receptors and perforin-dependent killing mechanisms. However, NK cells remain distinct by virtue of their capacity to kill target cells without any prior sensitization or MHC restriction (6). This has led to their wide use in adoptive cancer immunotherapy, despite our incomplete understanding of the regulatory mechanisms and activation requirements that are needed for successful therapeutic approaches. In this review article, we summarize NK cell recognition strategies of tumor targets and the signaling requirements for NK cell-mediated lysis. We also discuss properties of tumor-associated NK cells in light of cancer immune evasion and an unmet activation threshold for NK cell lysis.

\section{NK CELL RECOGNITION OF TUMORS}

Originally viewed as simple effector cells with a "natural" capacity for killing, NK cells were believed to be the ancestral forerunners of the seemingly more sophisticated T lymphocytes and classed within the innate arm of the immune system. Since then, more sophisticated features that are characteristic of adaptive immunity have been shown to occur in NK cells, including priming, education, and memory (7). Prior to the discovery of NK cell receptors, it was unclear how NK cells could distinguish target cells from normal cells for lysis. The "missing-self" hypothesis was proposed based on the observation that NK cells kill targets with reduced or absent self MHC class I molecules, a phenomenon common to virally infected and transformed cells $(8,9)$. The subsequent characterization of NK cell inhibitory receptors supported this hypothesis by explaining the molecular mechanisms by which NK cells sensed the downregulation of MHC class I expression (10-19). However, when studies began to show that the absence of MHC class I molecules on tumor cells was insufficient to trigger NK cell lysis, it became clear that our understanding of NK cell target recognition was incomplete $(20,21)$. As a wide array of activating receptors started to unravel, the "dynamic equilibrium" hypothesis was formulated, postulating that the integration of opposing signals from activating and inhibitory receptors determines the functional outcome of NK cell activity (22).

Recent evidence has shown that when the minimal requirements for NK cell cytotoxicity are met, tumor killing can occur irrespective of the presence of inhibitory signals, which suggests that proponents of the missing-self theory might have been overstating their case. NK cells are negatively regulated by killer Ig-like receptors (KIRs), which bind human leukocyte antigen (HLA)-A, $-\mathrm{B}$, and $-\mathrm{C}$, and C-type lectins, which form CD94/NKG2 receptor complexes recognizing HLA-E (23). The role of HLA-mediated inhibition in regulating NK cell activity is evidenced by studies showing that transfection of appropriate HLA-C alleles into NK susceptible target cells, such as K562, can render them resistant to NK-mediated lysis $(24,25)$. Additionally, NK-resistant tumors such as the B lymphoma cell line RAJI are known to constitutively express type I and II HLA-C alleles. In the clinical setting, transplantation across HLA barriers has been shown to trigger donor-NK-cell alloreactivity if the recipient lacks KIR-ligands that are present in the donor, which is known as "KIR-ligand mismatch" $(26,27)$. Studies involving acute myeloid leukemia (AML) patients have demonstrated that KIR-ligand incompatibility can 
improve survival and engraftment, and reduce the incidence of graft-versus-host disease (GVHD) (20). However, the impact of KIR-mismatch in other clinical settings remains very controversial with several studies showing no advantage of KIR-ligand incompatibility for survival or engraftment $(28,29)$. Pre-incubation of NK cells with an activating cytokine such as interleukin (IL)-2, resulting in the generation of lymphokine-activated killer cells (LAKs), can result in NK cell killing of targets that were previously resistant. Tumor target cells can also be used to activate NK cells in a manner analogous to IL-2, as we have previously demonstrated using the acute lymphoid leukemia cell line CTV1, which generated NK cells that are able to lyse NK-resistant tumor cell lines, primary leukemias, and solid tumors, in HLAmatched, allogeneic or autologous settings (30). Moreover, transfection of resistant, HLA-expressing RAJI cells with specific ligands for NK cell-activating receptors renders them susceptible to NK cell lysis (31). Similarly, blockade of certain tumor ligands for activating NK cell receptors on non-HLA-expressing, sensitive K562 cells makes them resistant to NK cell-mediated killing. Thus, providing NK cells with the appropriate combination of activating stimuli unleashes full effector function, such that an NK cell can kill tumor targets even in the presence of strong inhibitory signaling. Building on this knowledge, we aim to further define NK cell activation requirements for tumor killing.

\section{TUMOR ACTIVATION OF NK CELLS}

Natural killer cells require the co-engagement of multiple activating receptors in order to exhibit natural cytotoxicity against tumor target cells (32). Work by our group further defined this co-stimulation into two discrete stages, priming and triggering (30). The priming signal can be delivered by an activating cytokine in the tumor microenvironment or a target cell expressing the appropriate intensity and combination of ligands for NK cell activating receptors. The second stage, "triggering," requires the coengagement of at least one additional NK cell activating receptor, specific to stressed cells, in order to avoid autoreactivity.

Upon encounter with potential target cells, an immunological synapse forms at the point of contact between the NK cell and the target cell, where NK cell receptors can interact with their respective ligands. Given sufficient activation signals, NK cell cytoskeletal rearrangements are initiated, which result in the polarization of NK cell lytic granules toward the immunological synapse, where they eventually fuse and release their cytotoxic contents on to the target cell (33). In contrast to CTLs, NK cells have their cytotoxic granules preformed before target cell recognition, and so their release is initially constrained until sufficient signaling is achieved (33). NK cells have been shown to establish cytoskeletal polarity more slowly compared to CTLs, and to have a unique sensitivity to minor interference with cytoskeletal dynamics (34).

Work by Bryceson et al. showed that the co-engagement of lymphocyte function-associated antigen (LFA)-1 with any of the activating receptors, NK group 2 membrane D (NKG2D), DNAX accessory molecule (DNAM)-1, 2B4 or CD2, is sufficient to establish adhesion, conjugate formation, and granule polarization in NK cells $(35,36)$. We had previously identified CD2-CD15 interactions as part of the NK priming signal delivered by the leukemic target cell CTV-1, which primes NK cells to kill tumor targets that were previously resistant (31). CTV-1 also expresses ICAM-1, the natural ligand for LFA-1, which has been shown to deliver signals that are crucial for successful NK-target cell conjugate formation (37). This stepwise progression in effector function with specific signaling requirements provides a mechanistic explanation of how the spontaneous capacity of NK cells for killing is regulated (Figure 1). After NK cell-mediated killing of a tumor target cell is achieved, an NK cell is able to restart the activation cycle with the next target cell encounter. IL-2-activated NK cells have the capacity to serially hit up to four target cells (38).

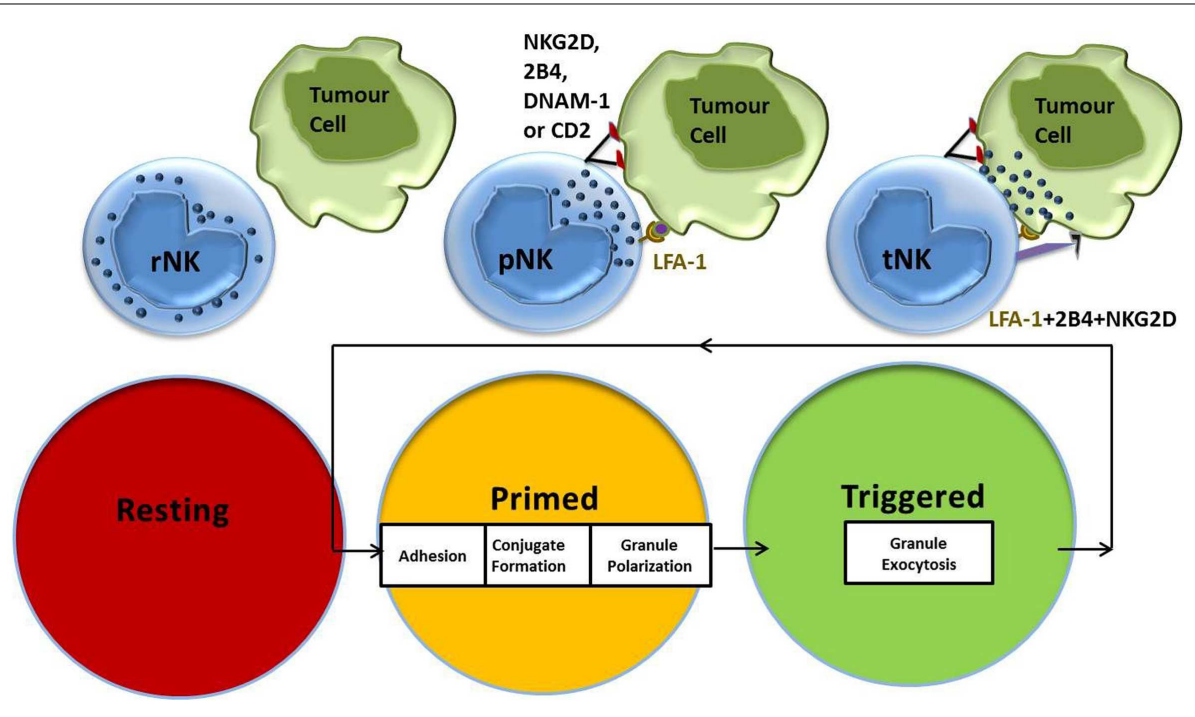

FIGURE 1 | NK cell activation stages and signaling requirements for natural cytotoxicity. Resting NK cells require an initial priming signal delivered by an activating cytokine or a target cell expressing the ligands necessary to induce adhesion, conjugate formation, and granule polarization. Co-stimulation of additional NK cell activating receptors by the triggering ligands results in NK cell-mediated cytotoxicity against target cells. 


\section{NK CELL DYSFUNCTION IN CANCER: NOT A DYSFUNCTION}

It is widely thought that cancer patients have immune dysfunctions that are secondary to the presence and progression of their disease (39). Commonly reported NK cell functional impairments in cancer include decreased cytotoxic activity (40-53), downregulation of activating receptor expression $(21,44,54-56)$ and intracellular signaling molecules (57-61), defective proliferation (62-64), poor infiltration, decreased cell counts, and defective cytokine production $(51,53,65)$. It is important to note that studies since the late 1980s have demonstrated the reversal of these tumor-associated NK cell traits after a few days of ex vivo culturing alone or with IL-2, suggesting the absence of any inherent NK cell defect per se (66). Instead, we propose that these observations are in fact indicative of a tumor-specific NK cell response, bearing in mind that the tumor itself has undergone selective pressure to grow in an immunocompetent setting.

The weakened capacity of NK cells to kill tumor targets has previously been shown to be "corrected" with the addition of activating stimuli, blockade of inhibitory factors, or when tested against an allogeneic tumor $(62,63)$. The observation that NK cell-mediated killing of tumor target cells occurs without having undergone any restorative measures is in itself evidence against NK cell functional impairment or incapacity. Loss of $\mathrm{CD} 3-\zeta$ expression is the most frequently cited example of a defective NK cell phenotype and since some of the most important NK cell activating receptors involved in tumor killing are associated with $\mathrm{CD} 3-\zeta$, including CD16 (67) and several NCRs $(61,68,69)$, a generalized loss of function is expected. However, tumor-primed NK cells, which have been shown to have enhanced effector functions, also exhibit marked downregulation of numerous activating receptors (31). More importantly, several studies have reported better killing of tumor targets by NK cell subsets with downregulated receptors such as CD16 or NKp46 compared with their counterparts with normal expression $(62,70)$. This argues that ligand-induced downregulation of NK cell activating receptors is part of the NK cell response, as has been previously reported (71-74).

Recent studies have highlighted hierarchies in the strength of the activating stimuli required for specific NK cell responses (35, $36,75)$. Inside-out signals for LFA-1-dependent adhesion and release of chemokines such as macrophage inflammatory protein (MIP)-1 $\beta$, exhibit a low threshold for activation, which can be met through the engagement of a single NK cell activating receptor. Degranulation and the release of other cytokines such as tumor necrosis factor (TNF)- $\alpha$ require stronger activating stimuli. Interferon (IFN)- $\gamma$ displays the most stringent requirements for induction and the highest activation threshold for NK cell receptor cooperation (76). Thus, defective cytokine production by tumor-associated NK cells, which is often reported as a decrease in INF- $\gamma$ release, can be explained by the absence of sufficient activating signals necessary for its secretion.

Similar to NK cells, tumor-associated T lymphocytes can recognize and eliminate autologous tumors after ex vivo culture with IL-2 $(60,77,78)$, or anti-CD28 and anti-CD3 mAbs (79), despite their inability to kill those targets in situ. Chronic stimulation of $\mathrm{T}$ cells, in the absence of a second activation signal has also been shown to decrease $\mathrm{T}$ cell receptor expression, proliferative capacity, and responsiveness (80). It can be easily envisaged that chronic stimulation of NK cells such as in an inflammatory/autoimmune disease setting, results in a similar reduction in proliferation and response. Collectively, the observations discussed above argue against an inherent NK cell defect in cancer patients and suggest the absence of sufficient activating signals for full NK cell effector function in the tumor microenvironment. A tumor-primed NK cell, waiting for the second signal to trigger killing, is likely to have downregulated receptors involved in the priming stage, but is still functional and ready for killing upon receipt of secondary stimulation. Interestingly, pre-treatment of tumor cells with histone deacetylase inhibitors, depsipeptide or bortezomib, renders them susceptible to autologous NK cell killing, which suggests that resistance of the tumor target to NK cell-mediated cytotoxicity is determined by tumor-specific gene expression (81).

\section{TUMOR EVASION OF NK CELLS}

The theory of cancer immunosurveillance, as proposed by Burnet and Thomas in 1957 (82), dictates that immune cells continuously monitor the body such that any threat to the immune system is detected and eliminated. Although abandoned shortly after for lack of sufficient experimental evidence (83-86), the subsequent discovery of NK cells led to considerable enthusiasm over the possibility that they function as one of the main effector cells of immunosurveillance (87). Recent studies clearly show the existence of cancer immunosurveillance and support the concept that NK cells play a critical role in tumor control and eradication (88). Evidence for cancer immunosurveillance by NK cells in humans include an 11-year follow-up study of 3500 normal, healthy individuals showing that low NK cell cytotoxicity correlates with an increased risk for cancer (89). The addition of immune evasion as an emerging "hallmark" of cancer, highlights the revival of support for the immunosurveillance theory (90). It is now believed that tumors acquire a set of biological capabilities during their development that allow them to overcome barriers, one of which is likely to be NK cell-mediated anti-tumor immunity. These capabilities are acquired with the help of recruited inflammatory cells and soluble factors in the tumor microenvironment, which play an active role in the process of tumorigenesis.

Early on in the study of NK cell interactions with tumors, Kiessling et al. (39) proposed that cancer evasion of NK cells involves two stages: the early stages of tumor formation and growth are associated with antigen-specific tolerance, whereas the later stages elicit a more generalized state of immunodeficiency. The concept of cancer immunoediting, as introduced by Dunn et al. argues that the immune system plays a role during tumor formation by selecting less immunogenic variants for survival in an immunologically intact environment. Tumors are thus "imprinted" by the immunologic environment in which they form, and only those that have acquired capabilities to evade or suppress immune attack remain. O'Sullivan et al. recently demonstrated that cancer immunoediting by the innate immune system requires NK cell derived IFN- $\gamma$, which activates M1 macrophages to function as innate editors (91). Based on evidence for a two-stage hypothesis for NK cell-mediated killing of tumors, we propose that tumors evade NK cell attack directly by lacking either the priming or triggering ligands such that the activation threshold for NK cell granule exocytosis is not met. Once successful 


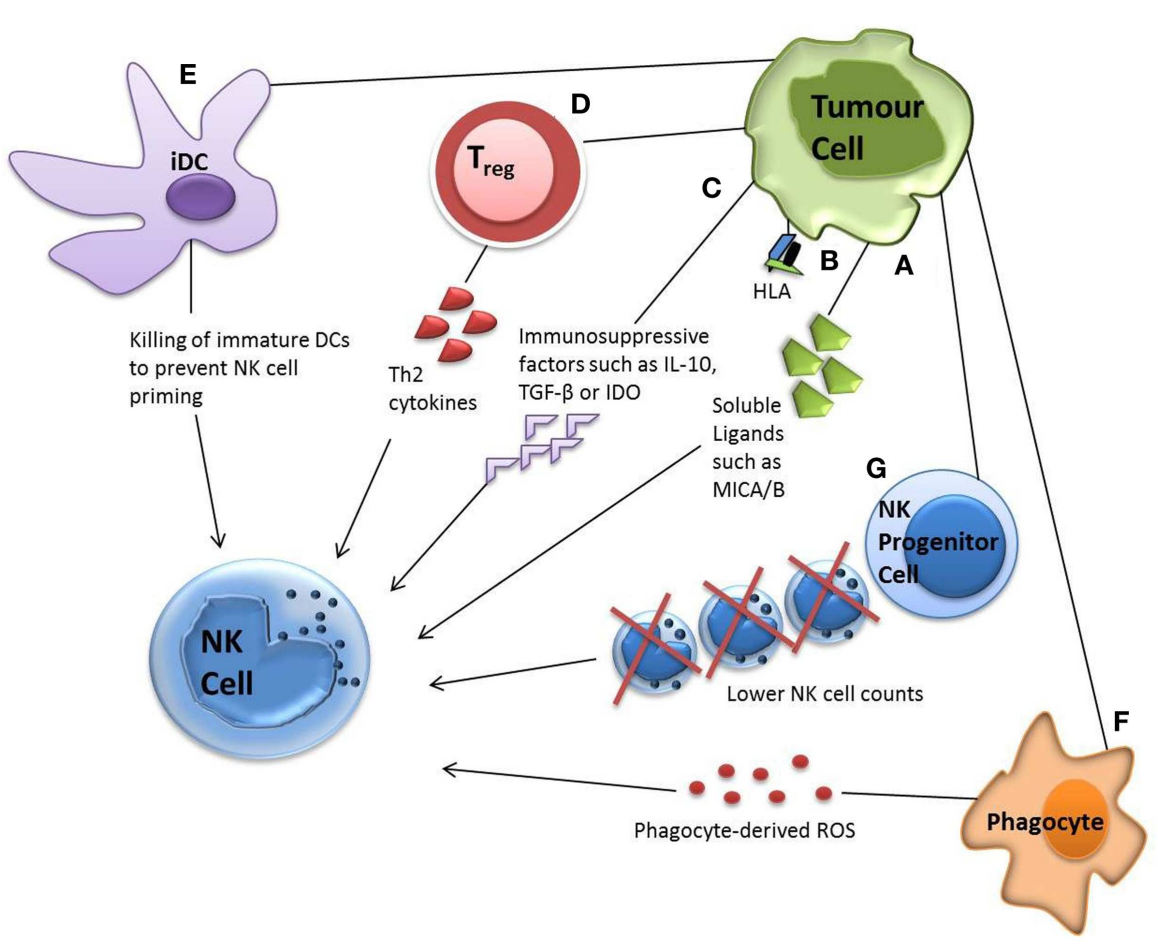

FIGURE 2 |Tumor evasion strategies. Tumor cells can evade NK cell attack via direct or indirect mechanisms. Direct mechanisms include (A) shedding soluble ligands for NK cell activating receptors (B) upregulation of HLA molecules and $(\mathbf{C})$ release of inhibitory cytokines. Indirect mechanisms include (D) activation of inhibitory regulatory $T$ cells (E) dendritic cell killing and (F) phagocyte-derived inhibitory cytokines. Tumor cells have also been shown to decrease the number of NK progenitor cells $(\mathbf{G})$, hence lowering NK cell counts. evasion of NK cell attack is achieved, the tumor begins to create the microenvironment necessary for its continued growth.

Direct evasion of NK cells by tumor targets can be accompanied by various other escape mechanisms. For example, tumors have been shown to minimally express or shed ligands for important NK cell receptors, such as NKG2D ligands UL16-binding protein 2, major histocompatibility complex (MHC) class I chain-related molecules A and B molecules (MICA/MICB). They have also been reported to upregulate MHC class I, soluble MIC and FasL expression in order to increase inhibitory signaling (21, 92-94). The release of immunosuppressive factors such as IL-10, TGF- $\beta$, and indoleamine 2,3-dioxygense (IDO) by tumor targets has also been reported, which can suppress the adaptive anti-tumor immune response or skew the immune response toward a Th2 response with significantly less anti-tumor capacity (95-99) (Figure 2).

Indirect mechanisms for NK cell evasion by tumors can involve numerous cell types from the immune system. Recruitment of inflammatory cells that are actively immunosuppressive has been demonstrated, including regulatory T cells (Tregs), myeloidderived suppressor cells (MDSCs), and phagocytes secreting reactive oxygen species (ROS) (100). Some tumors alter their expressions of IL-6, IL-10, vascular epithelial growth factor or GM-CSF, impairing dendritic cell function and maturation, hence NK cell priming. Tumor growth has also been shown to decrease NK cell count by reducing the numbers of its lymphoid progenitor (101) (Figure 2).

\section{CONCLUSION - MOVING FORWARD}

Studies summarized here argue against inherent NK cell defects in cancer, based on their retained capacity for effector functions as well their differential activation profiles in response to varying stimuli. NK cell functional responses can be anti-tumoral, antiviral, or immunomodulatory, depending on the type of threat faced by the immune system and the activating NK cell signals received. Studies over the past decade have shown significant differences in specific NK cell responses according to the type of stimulus, be it an infected cell, a transformed cell or an exogenous cytokine. This should be taken into consideration in the application of strategies involving ex vivo culture of NK cells to enhance NK cell functional properties. In the case of cancer immunotherapy, studying tumor-specific responses of NK cells should be the focal point for better specificity and efficacy of treatments. Further defining NK cell activation stages as coupled by their requirements for receptor cooperation is critical, since it is clear that the entire answer does not lie in KIRmismatch and the overcoming of inhibitory signaling. A clear understanding of NK cell activation requirements at the bench may lead to novel therapeutic strategies for the treatment of cancer.

\section{ACKNOWLEDGMENTS}

We thank Dr. Fernando Gibson for critically reading the manuscript. We also thank members of our laboratory for fruitful 
discussions. May Sabry is supported by a scholarship from Citadel Capital Scholarship Foundation in Egypt.

\section{REFERENCES}

1. Herberman RB, Nunn ME, Holden HT, Lavrin DH. Natural cytotoxic reactivity of mouse lymphoid cells against syngeneic and allogeneic tumors. II. Characterization of effector cells. Int J Cancer (1975) 16(2):230-9. doi:10.1002/ijc. 2910160205

2. Herberman RB, Nunn ME, Lavrin DH. Natural cytotoxic reactivity of mouse lymphoid cells against syngeneic acid allogeneic tumors. I. Distribution of reactivity and specificity. Int J Cancer (1975) 16(2):216-29. doi:10.1002/ijc. 2910160205

3. Kiessling R, Klein E, Pross H, Wigzell H. "Natural" killer cells in the mouse. II. Cytotoxic cells with specificity for mouse Moloney leukemia cells. Characteristics of the killer cell. Eur J Immunol (1975) 5(2):117-21. doi:10.1002/eji. 1830050208

4. Kiessling R, Klein E, Wigzell H. "Natural" killer cells in the mouse. I. Cytotoxic cells with specificity for mouse Moloney leukemia cells. Specificity and distribution according to genotype. Eur J Immunol (1975) 5(2):112-7. doi:10.1002/eji.1830050208

5. Vivier E, Tomasello E, Baratin M, Walzer T, Ugolini S. Functions of natural killer cells. Nat Immunol (2008) 9(5):503-10. doi:10.1038/ni1582

6. Narni-Mancinelli E, Vivier E, Kerdiles YM. The 'T-cell-ness' of NK cells: unexpected similarities between NK cells and T cells. Int Immunol (2011) 23(7):427-31. doi:10.1093/intimm/dxr035

7. Paust S, Senman B, von Andrian UH. Adaptive immune responses mediated by natural killer cells. Immunol Rev (2010) 235(1):286-96. doi:10.1111/j.01052896.2010.00906.x

8. Karre K, Ljunggren HG, Piontek G, Kiessling R. Selective rejection of H-2deficient lymphoma variants suggests alternative immune defence strategy. Nature (1986) 319(6055):675-8. doi:10.1038/319675a0

9. Ljunggren HG, Karre K. In search of the 'missing self': MHC molecules and NK cell recognition. Immunol Today (1990) 11(7):237-44. doi:10.1016/01675699(90)90097-S

10. Colonna M, Samaridis J. Cloning of immunoglobulin-superfamily members associated with HLA-C and HLA-B recognition by human natural killer cells. Science (1995) 268(5209):405-8. doi:10.1126/science.7716543

11. D’Andrea A, Chang C, Franz-Bacon K, McClanahan T, Phillips JH, Lanier LL. Molecular cloning of NKB1. A natural killer cell receptor for HLA-B allotypes. J Immunol (1995) 155(5):2306-10.

12. Karlhofer FM, Ribaudo RK, Yokoyama WM. MHC class I alloantigen specificity of Ly-49+ IL-2-activated natural killer cells. Nature (1992) 358(6381):66-70. doi:10.1038/358066a0

13. Wagtmann N, Biassoni R, Cantoni C, Verdiani S, Malnati MS, Vitale M, et al. Molecular clones of the p58 NK cell receptor reveal immunoglobulin-related molecules with diversity in both the extra- and intracellular domains. Immunity (1995) 2(5):439-49. doi:10.1016/1074-7613(95)90025-X

14. Brooks AG, Posch PE, Scorzelli CJ, Borrego F, Coligan JE. NKG2A complexed with CD94 defines a novel inhibitory natural killer cell receptor. J Exp Med (1997) 185(4):795-800. doi:10.1084/jem.185.4.795

15. Carretero M, Cantoni C, Bellon T, Bottino C, Biassoni R, Rodriguez A, et al. The CD94 and NKG2-A C-type lectins covalently assemble to form a natural killer cell inhibitory receptor for HLA class I molecules. Eur J Immunol (1997) 27(2):563-7. doi:10.1002/eji.1830270230

16. Lazetic S, Chang C, Houchins JP, Lanier LL, Phillips JH. Human natural killer cell receptors involved in MHC class I recognition are disulfide-linked heterodimers of CD94 and NKG2 subunits. J Immunol (1996) 157(11):4741-5.

17. Moretta A, Vitale M, Sivori S, Bottino C, Morelli L, Augugliaro R, et al. Human natural killer cell receptors for HLA-class I molecules. Evidence that the Kp43 (CD94) molecule functions as receptor for HLA-B alleles. J Exp Med (1994) 180(2):545-55. doi:10.1084/jem.180.2.545

18. Phillips JH, Chang C, Mattson J, Gumperz JE, Parham P, Lanier LL. CD94 and a novel associated protein (94AP) form a NK cell receptor involved in the recognition of HLA-A, HLA-B, and HLA-C allotypes. Immunity (1996) 5(2):163-72. doi:10.1016/S1074-7613(00)80492-6

19. Sivori S, Vitale M, Bottino C, Marcenaro E, Sanseverino L, Parolini S, et al. CD94 functions as a natural killer cell inhibitory receptor for different HLA class I alleles: identification of the inhibitory form of CD94 by the use of novel monoclonal antibodies. Eur J Immunol (1996) 26(10):2487-92. doi:10.1002/eji.1830261032

20. Ruggeri L. Effectiveness of donor natural killer cell alloreactivity in mismatched hematopoietic transplants. Science (2002) 295(5562):2097-100. doi:10.1126/ science. 1068440

21. Costello RT, Sivori S, Marcenaro E, Lafage-Pochitaloff M, Mozziconacci MJ, Reviron D, et al. Defective expression and function of natural killer celltriggering receptors in patients with acute myeloid leukemia. Blood (2002) 99(10):3661-7. doi:10.1182/blood.V99.10.3661

22. Brumbaugh KM, Binstadt BA, Leibson PJ. Signal transduction during NK cell activation: balancing opposing forces. Curr Top Microbiol Immunol (1998) 230:103-22. doi:10.1007/978-3-642-46859-9_8

23. Moretta L, Mingari MC, Bottino C, Pende D, Biassoni R, Moretta A. Cellular and molecular basis of natural killer and natural killer-like activity. Immunol Lett (2003) 88(2):89-93. doi:10.1016/S0165-2478(03)00074-9

24. Addison EG, North J, Bakhsh I, Marden C, Haq S, Al-Sarraj S, et al. Ligation of CD8alpha on human natural killer cells prevents activation-induced apoptosis and enhances cytolytic activity. Immunology (2005) 116(3):354-61. doi:10.1111/j.1365-2567.2005.02235.x

25. Ciccone E, Pende D, Viale O, Than A, Di DC, Orengo AM, et al. Involvement of HLA class I alleles in natural killer (NK) cell-specific functions: expression of HLA-Cw3 confers selective protection from lysis by alloreactive NK clones displaying a defined specificity (specificity 2). J Exp Med (1992) 176(4):963-71. doi:10.1084/jem.176.4.963

26. Farag SS, Fehniger TA, Ruggeri L, Velardi A, Caligiuri MA. Natural killer cell receptors: new biology and insights into the graft-versus-leukemia effect. Blood (2002) 100(6):1935-47. doi:10.1182/blood-2002-02-0350

27. Parham P, McQueen KL. Alloreactive killer cells: hindrance and help for haematopoietic transplants. Nat Rev Immunol (2003) 3(2):108-22. doi:10. 1038/nri999

28. Davies SM, Ruggieri L, DeFor T, Wagner JE, Weisdorf DJ, Miller JS, et al. Evaluation of KIR ligand incompatibility in mismatched unrelated donor hematopoietic transplants. Killer immunoglobulin-like receptor. Blood (2002) 100(10):3825-7. doi:10.1182/blood-2002-04-1197

29. Malmberg KJ, Schaffer M, Ringden O, Remberger M, Ljunggren HG. KIRligand mismatch in allogeneic hematopoietic stem cell transplantation. Mol Immunol (2005) 42(4):531-4. doi:10.1016/j.molimm.2004.07.037

30. North J, Bakhsh I, Marden C, Pittman H, Addison E, Navarrete C, et al. Tumorprimed human natural killer cells lyse NK-resistant tumor targets: evidence of a two-stage process in resting NK cell activation. J Immunol (2007) 178(1):85-94.

31. Sabry M, Tsirogianni M, Bakhsh IA, North J, Sivakumaran J, Giannopoulos K, et al. Leukemic priming of resting NK cells is killer Ig-like receptor independent but requires $\mathrm{CD} 15$-mediated $\mathrm{CD} 2$ ligation and natural cytotoxicity receptors. J Immunol (2011) 187(12):6227-34. doi:10.4049/jimmunol.1101640

32. Bryceson YT, March ME, Ljunggren HG, Long EO. Synergy among receptors on resting NK cells for the activation of natural cytotoxicity and cytokine secretion. Blood (2006) 107(1):159-66. doi:10.1182/blood-2005-04-1351

33. Orange JS. Formation and function of the lytic NK-cell immunological synapse. Nat Rev Immunol (2008) 8(9):713-25. doi:10.1038/nri2381

34. Wulfing C, Purtic B, Klem J, Schatzle JD. Stepwise cytoskeletal polarization as a series of checkpoints in innate but not adaptive cytolytic killing. Proc Natl Acad Sci U S A (2003) 100(13):7767-72. doi:10.1073/pnas.1336920100

35. Bryceson YT, March ME, Barber DF, Ljunggren HG, Long EO. Cytolytic granule polarization and degranulation controlled by different receptors in resting NK cells. J Exp Med (2005) 202(7):1001-12. doi:10.1084/jem.20051143

36. Bryceson YT, Ljunggren HG, Long EO. Minimal requirement for induction of natural cytotoxicity and intersection of activation signals by inhibitory receptors. Blood (2009) 114(13):2657-66. doi:10.1182/blood-2009-01-201632

37. Barber DF, Faure M, Long EO. LFA-1 contributes an early signal for NK cell cytotoxicity. J Immunol (2004) 173(6):3653-9.

38. Bhat R, Watzl C. Serial killing of tumor cells by human natural killer cells - enhancement by therapeutic antibodies. PLoS One (2007) 2(3):e326. doi:10.1371/journal.pone.0000326

39. Kiessling R, Wasserman K, Horiguchi S, Kono K, Sjoberg J, Pisa P, et al. Tumor-induced immune dysfunction. Cancer Immunol Immunother (1999) 48(7):353-62. doi:10.1007/s002620050586

40. Bauernhofer T, Kuss I, Henderson B, Baum AS, Whiteside TL. Preferential apoptosis of CD56dim natural killer cell subset in patients with cancer. Eur J Immunol (2003) 33(1):119-24. doi:10.1002/immu.200390014 
41. Campos MM, de Souza MH, Pires V, Scheiner MA, Esteves EB, Ornellas AA. Clinical implications of natural killer cytotoxicity in patients with squamous cell carcinoma of the penis. Nat Immun (1998) 16(5-6):256-62. doi:10.1159/000069451

42. Carrega P, Morandi B, Costa R, Frumento G, Forte G, Altavilla G, et al. Natural killer cells infiltrating human nonsmall-cell lung cancer are enriched in CD56 bright CD16(-) cells and display an impaired capability to kill tumor cells. Cancer (2008) 112(4):863-75. doi:10.1002/cncr.23239

43. Frassanito MA, Silvestris F, Cafforio P, Silvestris N, Dammacco F. IgG Mcomponents in active myeloma patients induce a down-regulation of natural killer cell activity. Int J Clin Lab Res (1997) 27(1):48-54. doi:10.1007/ BF02827242

44. Jinushi M, Takehara T, Tatsumi T, Hiramatsu N, Sakamori R, Yamaguchi S, et al. Impairment of natural killer cell and dendritic cell functions by the soluble form of MHC class I-related chain A in advanced human hepatocellular carcinomas. J Hepatol (2005) 43(6):1013-20. doi:10.1016/j.jhep.2005.05.026

45. Katrinakis G, Kyriakou D, Papadaki H, Kalokyri I, Markidou F, Eliopoulos GD. Defective natural killer cell activity in B-cell chronic lymphocytic leukaemia is associated with impaired release of natural killer cytotoxic factor(s) but not of tumor necrosis factor-alpha. Acta Haematol (1996) 96(1):16-23. doi:10.1159/000203709

46. Koda K, Saito N, Oda K, Seike K, Kondo E, Ishizuka M, et al. Natural killer cell activity and distant metastasis in rectal cancers treated surgically with and without neoadjuvant chemoradiotherapy. J Am Coll Surg (2003) 197(2):254-60. doi:10.1016/S1072-7515(03)00115-7

47. LeFever AV, Funahashi A. Phenotype and function of natural killer cells in patients with bronchogenic carcinoma. Cancer Res (1991) 51(20):5596-601.

48. Lutgendorf SK, Sood AK, Anderson B, McGinn S, Maiseri H, Dao M, et al. Social support, psychological distress, and natural killer cell activity in ovarian cancer. J Clin Oncol (2005) 23(28):7105-13. doi:10.1200/JCO.2005.10.015

49. Mocchegiani E, Ciavattini A, Santarelli L, Tibaldi A, Muzzioli M, Bonazzi P, et al. Role of zinc and alpha 2 macroglobulin on thymic endocrine activity and on peripheral immune efficiency (natural killer activity and interleukin 2) in cervical carcinoma. Br J Cancer (1999) 79(2):244-50. doi:10.1038/sj.bjc.6690040

50. Rajaram N, Tatake RJ, Advani SH, Naik SL, Gangal SG. Natural killer and lymphokine-activated killer cell functions in chronic myeloid leukemia. Cancer Immunol Immunother (1990) 31(1):44-8. doi:10.1007/BF01742494

51. Tajima F, Kawatani T, Endo A, Kawasaki H. Natural killer cell activity and cytokine production as prognostic factors in adult acute leukemia. Leukemia (1996) 10(3):478-82.

52. Taketomi A, Shimada M, Shirabe K, Kajiyama K, Gion T, Sugimachi K. Natural killer cell activity in patients with hepatocellular carcinoma: a new prognostic indicator after hepatectomy. Cancer (1998) 83(1):58-63. doi:10.1002/(SICI) 1097-0142(19980701)83:1<58::AID-CNCR8>3.0.CO;2-A

53. Wakiguchi H, Kubota H, Hisakawa H, Fujieda M, Kurashige T. Defective natural killer cell activity and deficient production of interferon-gamma in children with acute lymphoblastic leukemia. Acta Paediatr Jpn (1994) 36(4):361-5. doi:10.1111/j.1442-200X.1994.tb03201.x

54. El-Sherbiny YM, Meade JL, Holmes TD, McGonagle D, Mackie SL, Morgan AW, et al. The requirement for DNAM-1, NKG2D, and NKp46 in the natural killer cell-mediated killing of myeloma cells. Cancer Res (2007) 67(18):8444-9. doi:10.1158/0008-5472.CAN-06-4230

55. Fauriat C, Mallet F, Olive D, Costello RT. Impaired activating receptor expression pattern in natural killer cells from patients with multiple myeloma. Leukemia (2006) 20(4):732-3. doi:10.1038/sj.leu.2404096

56. Konjevic G, Mirjacic MK, Vuletic A, Jovic V, Jurisic V, Babovic N, et al. Low expression of CD161 and NKG2D activating NK receptor is associated with impaired NK cell cytotoxicity in metastatic melanoma patients. Clin Exp Metastasis (2007) 24(1):1-11. doi:10.1007/s10585-006-9043-9

57. Buggins AG, Hirst WJ, Pagliuca A, Mufti GJ. Variable expression of CD3-zeta and associated protein tyrosine kinases in lymphocytes from patients with myeloid malignancies. Br J Haematol (1998) 100(4):784-92. doi:10.1046/j. 1365-2141.1998.00654.x

58. Healy CG, Simons JW, Carducci MA, DeWeese TL, Bartkowski M, Tong KP, et al. Impaired expression and function of signal-transducing zeta chains in peripheral $\mathrm{T}$ cells and natural killer cells in patients with prostate cancer. Cytometry (1998) 32(2):109-19. doi:10.1002/(SICI)1097-0320(19980601)32: $2<109:: A I D-C Y T O 6>3.0 . C O ; 2-G$
59. Kono K, Ressing ME, Brandt RM, Melief CJ, Potkul RK, Andersson B, et al. Decreased expression of signal-transducing zeta chain in peripheral $\mathrm{T}$ cells and natural killer cells in patients with cervical cancer. Clin Cancer Res (1996) 2(11):1825-8.

60. Lai P, Rabinowich H, Crowley-Nowick PA, Bell MC, Mantovani G, Whiteside TL. Alterations in expression and function of signal-transducing proteins in tumor-associated $\mathrm{T}$ and natural killer cells in patients with ovarian carcinoma. Clin Cancer Res (1996) 2(1):161-73.

61. Nakagomi H, Petersson M, Magnusson I, Juhlin C, Matsuda M, Mellstedt H, et al. Decreased expression of the signal-transducing zeta chains in tumorinfiltrating T-cells and NK cells of patients with colorectal carcinoma. Cancer Res (1993) 53(23):5610-2.

62. Gati A, Da RS, Guerra N, Escudier B, Moretta A, Chouaib S, et al. Analysis of the natural killer mediated immune response in metastatic renal cell carcinoma patients. Int J Cancer (2004) 109(3):393-401. doi:10.1002/ijc.11730

63. Pierson BA, Miller JS. CD56+bright and CD56+dim natural killer cells in patients with chronic myelogenous leukemia progressively decrease in number, respond less to stimuli that recruit clonogenic natural killer cells, and exhibit decreased proliferation on a per cell basis. Blood (1996) 88(6):2279-87.

64. Tsukuda M, Sawaki S, Yanoma S. Suppressed cellular immunity in patients with nasopharyngeal carcinoma. J Cancer Res Clin Oncol (1993) 120(1-2):115-8. doi:10.1007/BF01200735

65. Chang WC, Fujimiya Y, Casteel N, Pattengale P. Natural killer cell immunodeficiency in patients with chronic myelogenous leukemia. III. Defective interleukin-2 production by T-helper and natural killer cells. Int J Cancer (1989) 43(4):591-7. doi:10.1002/ijc.2910430410

66. Lotzova E, Savary CA, Herberman RB. Induction of NK cell activity against fresh human leukemia in culture with interleukin 2. J Immunol (1987) 138(8):2718-27.

67. Wirthmueller U, Kurosaki T, Murakami MS, Ravetch JV. Signal transduction by Fc gamma RIII (CD16) is mediated through the gamma chain. J Exp Med (1992) 175(5):1381-90. doi:10.1084/jem.175.5.1381

68. Anderson P, Caligiuri M, O'Brien C, Manley T, Ritz J, Schlossman SF. Fc gamma receptor type III (CD16) is included in the zeta NK receptor complex expressed by human natural killer cells. Proc Natl Acad Sci U S A (1990) 87(6):2274-8. doi:10.1073/pnas.87.6.2274

69. Vitale M, Bottino C, Sivori S, Sanseverino L, Castriconi R, Marcenaro E, et al. NKp44, a novel triggering surface molecule specifically expressed by activated natural killer cells, is involved in non-major histocompatibility complex-restricted tumor cell lysis. J Exp Med (1998) 187(12):2065-72. doi:10.1084/jem.187.12.2065

70. Penack O, Gentilini C, Fischer L, Asemissen AM, Scheibenbogen C, Thiel E, et al. CD56dimCD16neg cells are responsible for natural cytotoxicity against tumor targets. Leukemia (2005) 19(5):835-40. doi:10.1038/sj.leu.2403704

71. Groh V, Wu J, Yee C, Spies T. Tumor-derived soluble MIC ligands impair expression of NKG2D and T-cell activation. Nature (2002) 419(6908):734-8. doi:10.1038/nature01112

72. Huard B, Karlsson L. KIR expression on self-reactive CD8+ T cells is controlled by T-cell receptor engagement. Nature (2000) 403(6767):325-8. doi:10.1038/ 35002105

73. Linsley PS, Bradshaw J, Urnes M, Grosmaire L, Ledbetter JA. CD28 engagement by B7/BB-1 induces transient down-regulation of CD28 synthesis and prolonged unresponsiveness to CD28 signaling. J Immunol (1993) 150(8 Pt 1):3161-9.

74. Valitutti S, Muller S, Salio M, Lanzavecchia A. Degradation of T cell receptor (TCR)-CD3-zeta complexes after antigenic stimulation. J Exp Med (1997) 185(10):1859-64. doi:10.1084/jem.185.10.1859

75. Fauriat C, Long EO, Ljunggren HG, Bryceson YT. Regulation of human NK-cell cytokine and chemokine production by target cell recognition. Blood (2010) 115(11):2167-76. doi:10.1182/blood-2009-08-238469

76. Bryceson YT, Chiang SC, Darmanin S, Fauriat C, Schlums H, Theorell J, et al. Molecular mechanisms of natural killer cell activation. J Innate Immun (2011) 3(3):216-26. doi:10.1159/000325265

77. Matsuda M, Petersson M, Lenkei R, Taupin JL, Magnusson I, Mellstedt H, et al. Alterations in the signal-transducing molecules of T cells and NK cells in colorectal tumor-infiltrating, gut mucosal and peripheral lymphocytes: correlation with the stage of the disease. Int J Cancer (1995) 61(6):765-72. doi:10.1002/ijc.2910610605 
78. Mulder WM, Bloemena E, Stukart MJ, Kummer JA, Wagstaff J, Scheper RJ. T cell receptor-zeta and granzyme B expression in mononuclear cell infiltrates in normal colon mucosa and colon carcinoma. Gut (1997) 40(1):113-9.

79. Renner C, Ohnesorge S, Held G, Bauer S, Jung W, Pfitzenmeier JP, et al. T cells from patients with Hodgkin's disease have a defective T-cell receptor zeta chain expression that is reversible by T-cell stimulation with CD3 and CD28. Blood (1996) 88(1):236-41.

80. Correa MR, Ochoa AC, Ghosh P, Mizoguchi H, Harvey L, Longo DL. Sequential development of structural and functional alterations in $\mathrm{T}$ cells from tumorbearing mice. J Immunol (1997) 158(11):5292-6.

81. Lundqvist A, Abrams SI, Schrump DS, Alvarez G, Suffredini D, Berg M, et al. Bortezomib and depsipeptide sensitize tumors to tumor necrosis factorrelated apoptosis-inducing ligand: a novel method to potentiate natural killer cell tumor cytotoxicity. Cancer Res (2006) 66(14):7317-25. doi:10.1158/00085472.CAN-06-0680

82. Burnet M. Cancer; a biological approach. I. The processes of control. Br Med J (1957) 1(5022):779-86. doi:10.1136/bmj.1.5022.779

83. Rygaard J, Povlsen CO. The mouse mutant nude does not develop spontaneous tumors. An argument against immunological surveillance. Acta Pathol Microbiol Scand B Microbiol Immunol (1974) 82(1):99-106.

84. Rygaard J, Povlsen CO. Is immunological surveillance not a cellmediated immune function? Transplantation (1974) 17(1):135-6. doi:10.1097/ 00007890-197401000-00023

85. Stutman O. Tumor development after 3-methylcholanthrene in immunologically deficient athymic-nude mice. Science (1974) 183(4124):534-6. doi:10. 1126/science.183.4124.534

86. Stutman O. Chemical carcinogenesis in nude mice: comparison between nude mice from homozygous matings and heterozygous matings and effect of age and carcinogen dose. J Natl Cancer Inst (1979) 62(2):353-8.

87. Herberman RB, Holden HT. Natural cell-mediated immunity. Adv Cancer Res (1978) 27:305-77. doi:10.1016/S0065-230X(08)60936-7

88. Waldhauer I, Steinle A. NK cells and cancer immunosurveillance. Oncogene (2008) 27(45):5932-43. doi:10.1038/onc.2008.267

89. Imai K, Matsuyama S, Miyake S, Suga K, Nakachi K. Natural cytotoxic activity of peripheral-blood lymphocytes and cancer incidence: an 11-year follow-up study of a general population. Lancet (2000) 356(9244):1795-9. doi:10.1016/S0140-6736(00)03231-1

90. Hanahan D, Weinberg RA. Hallmarks of cancer: the next generation. Cell (2011) 144(5):646-74. doi:10.1016/j.cell.2011.02.013

91. O’Sullivan T, Saddawi-Konefka R, Vermi W, Koebel CM, Arthur C, White JM, et al. Cancer immunoediting by the innate immune system in the absence of adaptive immunity. J Exp Med (2012) 209(10):1869-82. doi:10.1084/jem. 20112738

92. Bennett MW, O’Connell J, O’Sullivan GC, Brady C, Roche D, Collins JK, et al. The Fas counterattack in vivo: apoptotic depletion of tumor-infiltrating lymphocytes associated with Fas ligand expression by human esophageal carcinoma. J Immunol (1998) 160(11):5669-75.

93. Maki G, Krystal G, Dougherty G, Takei F, Klingemann HG. Induction of sensitivity to NK-mediated cytotoxicity by TNF-alpha treatment: possible role of ICAM-3 and CD44. Leukemia (1998) 12(10):1565-72. doi:10.1038/sj.leu. 2401145

94. Yamauchi A, Taga K, Mostowski HS, Bloom ET. Target cell-induced apoptosis of interleukin-2-activated human natural killer cells: roles of cell surface molecules and intracellular events. Blood (1996) 87(12):5127-35.

95. Morse MA, Mosca PJ, Clay TM, Lyerly HK. Dendritic cell maturation in active immunotherapy strategies. Expert Opin Biol Ther (2002) 2(1):35-43. doi:10.1517/14712598.2.1.35

96. Orleans-Lindsay JK, Barber LD, Prentice HG, Lowdell MW. Acute myeloid leukaemia cells secrete a soluble factor that inhibits T and NK cell proliferation but not cytolytic function - implications for the adoptive immunotherapy of leukaemia. Clin Exp Immunol (2001) 126(3):403-11. doi:10.1046/j.1365-2249. 2001.01692.x

97. Shields JD, Kourtis IC, Tomei AA, Roberts JM, Swartz MA. Induction of lymphoid like stroma and immune escape by tumors that express the chemokine CCL21. Science (2010) 328(5979):749-52. doi:10.1126/science.1185837

98. Yang L, Pang Y, Moses HL. TGF-beta and immune cells: an important regulatory axis in the tumor microenvironment and progression. Trends Immunol (2010) 31(6):220-7. doi:10.1016/j.it.2010.04.002

99. Zagury D, Gallo RC. Anti-cytokine Ab immune therapy: present status and perspectives. Drug Discov Today (2004) 9(2):72-81. doi:10.1016/S1359-6446(03) 02955-6

100. Romero AI, Thoren FB, Brune M, Hellstrand K. NKp46 and NKG2D receptor expression in NK cells with CD56dim and CD56bright phenotype: regulation by histamine and reactive oxygen species. Br J Haematol (2006) 132(1):91-8. doi:10.1111/j.1365-2141.2005.05842.x

101. Richards J, McNally B, Fang X, Caligiuri MA, Zheng P, Liu Y. Tumor growth decreases NK and B cells as well as common lymphoid progenitor. PLoS One (2008) 3(9):e3180. doi:10.1371/journal.pone.0003180

Conflict of Interest Statement: Mark W. Lowdell is a consultant to Coronado Biosciences, which has licensed the patent to clinical commercialization of tumorprimed NK cells. The other co-author declares that the research was conducted in the absence of any commercial or financial relationships that could be construed as a potential conflict of interest.

Received: 25 September 2013; paper pending published: 17 October 2013; accepted: 11 November 2013; published online: 25 November 2013.

Citation: Sabry M and Lowdell MW (2013) Tumor-primed NK cells: waiting for the green light. Front. Immunol. 4:408. doi: 10.3389/fimmu.2013.00408

This article was submitted to NK Cell Biology, a section of the journal Frontiers in Immunology.

Copyright (c) 2013 Sabry and Lowdell. This is an open-access article distributed under the terms of the Creative Commons Attribution License (CC BY). The use, distribution or reproduction in other forums is permitted, provided the original author (s) or licensor are credited and that the original publication in this journal is cited, in accordance with accepted academic practice. No use, distribution or reproduction is permitted which does not comply with these terms. 